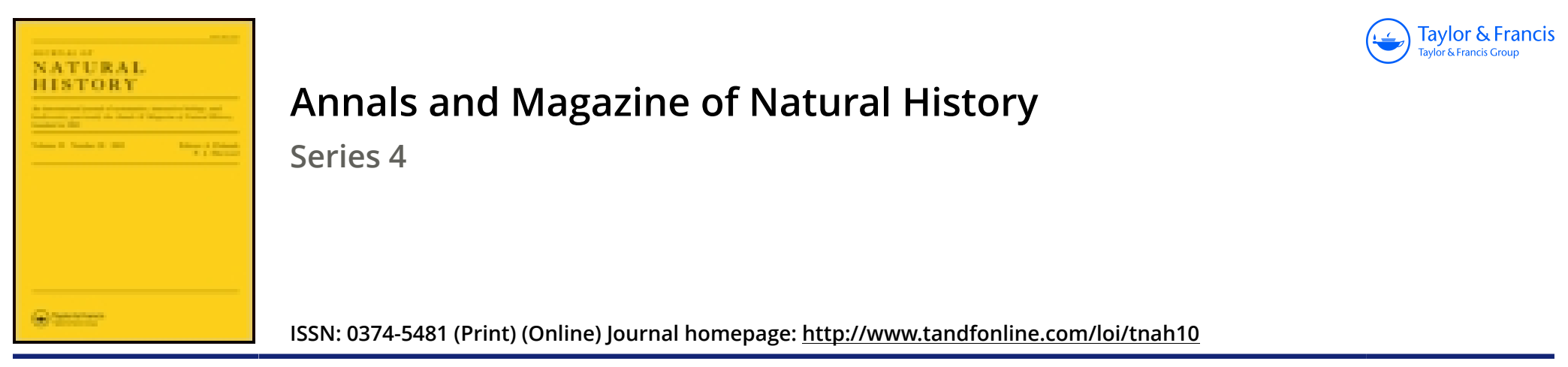

\title{
Descriptions of new species of Blattidæ belonging to the genus Panesthia
}

\author{
James Wood-Mason
}

To cite this article: James Wood-Mason (1877) Descriptions of new species of Blattidæ belonging to the genus Panesthia, Annals and Magazine of Natural History, 19:109, 117-118, DOI: $10.1080 / 00222937708682102$

To link to this article: http://dx.doi.org/10.1080/00222937708682102

曲 Published online: 15 Oct 2009.

Submit your article to this journal $[\pi$

Џll Article views: 4

Q View related articles 두 


\section{Descriptions of new Species of Blattidæ belonging to the Genus Panesthia. By James Wood-Mason.}

Panesthia monstruosa, n. sp.

Ingens, aptera, aterrima, nitida. Corpore crassissimo. Tegumento valde indurato. Pronoto in maribus valdissime, in feminis modice, inæquali et impresso ; bituberculato ; incisura profunda, lata, medio recta et linea elevata marginata, lateribus cornigera, cornibus in mare magnis, in femina modicis, reflexis, apice plicatis. Abdominis segmentis basalibus infra supraque sparsim minute punctatis, ultimo laminaque supraanali punctis crebrioribus necnon majoribus conspersis: hac postice 5-dentata. Pedibus validis, spinis tibialibus fortibus armatis; femoribus anticis trispinosis. Long. corporis maris 58 millim, ; pronoti $14 \frac{1}{3}$, pronoti lat. $19 \frac{1}{3}$, incisuræ lat. 6 ; mesonoti long. 9, mesonoti lat. $21 \frac{2}{3}$; metanoti long. 8, metanoti lat. 23; abdom. long. 30, abd. lat. (ad medium) 23. Long. corp. fem. 52.

$H a b$. A male and a female from Sonthern India (R. C. Beddome). This fine insect offers a curious resemblance to the Gromphadorhina portentosa, Schaum, from Madagascar.

\section{Panesthia Wallacei, n. sp.}

Aterrima, nitidissima. Pronoto ut in $P$. morione, sed nitidiore et distinctius crebriusque punctato. Abdomine sparsim punctulato, punctis apicem versus sensim frequentioribus ac paullo majoribus; segmento ultimo marginibus integro angulisque posticis vix producto ; lamina supraanali disco parce fulvo-pilosa, postice rotundata, tota integra, dentibus lateralibus nullis; lamina subgenitali confertim grosse punctata. Cercis tumidis, fulvo pilosis. Tegminibus alisque pæne ut in $P$. morione, abdominis apicem longe superantibus; venarum omnium parte apicali perspicua, utrinque pallida, subhyalina; illorum vena anali recta impressa hyalina. Fomoribus anticis basin versus bidentatis. Long. corporis maris $36 \frac{1}{2}$ millim.; pronoti $9 \frac{2}{3}$, pronoti lat. 14 ; long. tegminum 40 , alarum 35 ; abdom. 18, abd. lat. (ad medium) 16.

$\mathrm{Ha}$. A single male from Sinkep Island, near Singapore.

\section{Panesthia flavipennis, $\mathrm{n}$. sp.}

Aterrima, nitidissima, pulcherrima. Pronoto antice granulato, postice medio sparsim, ad latera confertissime punctato ; aliter ut in $P$. javanica. Oculis maculisque ocelliformibus flavidis. Tegminibus lætissime flavis, singulis maculis duabus nigris, una parva ad basin, alteraque magna orbiculari pone medium posita, notatis ; vena anali elevata potius quam impressa, fortiter arcuata; abdominis segmenti ultimi apicem vix attingentibus. Alis apice flavo marginatis. Antennis apicem versus flavido annulatis. Abdominis segmentis dorsalibus punctatissimis; ultimo laminaque supraanali punctis grossissimis : hac margine postico 5-dentato, angulis lateralibus latis : illo angulis posticis acutissime producto; 
segmentis ventralibus lateraliter punctatis, medio vix punctatis ; lamina subgenitali conspicua, lævi, politissima, convexa. Femoribus anticis muticis. Larvis totis aterrimis. Long. corporis of 37-45, q 43 millim.; pronoti o $10-13$, 오 $10 \frac{1}{3}$; pronoti lat. of $14 \frac{1}{2}-17 \frac{2}{3}$, ㅇ $16 \frac{1}{3}$; long. tegminum of 29-53, o $29 \frac{1}{2}$.

$H a b$. Numerous adult and immature specimens of both sexes from the Nágá hills (J. Butler and Godwin-Austen), Brahmaputra valley (A. W. Chennell), and Dikrang valley (Godwin-Austen).

\section{Panesthic Saussurii, n. sp.}

․ P. mandarinea, Saussure, Mélanges Orthopt. p. 100, pl. 3. fig. 23, non p. 40 , pl. 1. fig. 25.

I have recently received from Johore in the Malay peninsula a fine series of specimens of $P$. mandarinea, none of which exhibit the least approach to the remarkable structure of the abdomen seen in the insect described and figured by De Saussure as the supposed female of it. The larvæ of $P$. mandarinea, moreover, are jet-black throughout, while those of $P$. Saussurii are deep black-brown symmetrically variegated with pale testaceous on every part of the body, including the legs, which are ringed, the antennæ, which are tipped, and the head, which is triply banded, with the same colour. A further reason for refusing to accept the insect figured by De Saussure on pl. 3 (op. supra cit.) as the female of the one represented on pl. 1 is that the latter is itself also a female, the sides of the pronotum in the true males of which are produced into huge curved horns, each separated from the broad semioval median lobe covering the head by a deep rounded emargination.

Hab. A single specimen of the male from Sikkim (L. Mandelli). This insect having been captured just prior to the last moult, the organs of flight are still in rudiment, and the pronotum is still nonemarginate.-Journ. Asiatic Soc. Beng. vol. xlv. part 2, 1876.

\section{On some Facts relating to the Nutrition of the Embryo in the Egg of the Fowl. By M. C. Dareste.}

My investigations in experimental teratogeny have enabled me to ascertain some facts with regard to the nutrition of the embryo in the egg.

If in the first days of incubation we remove the blastoderm with the portion of the vitelline membrane that covers it, and the layer of albumen lining this section of the vitelline membrane, and then, after separating the blastoderm from the vitelline membrane, coagulate the albumen by means of alcohol or hot water, we find that the albumen has completely disappeared above the embryo. There is here a vacant space in the form of a hollow cylinder, or rather a portion of a cone with a circular base. This perforation of the albumen is the more considerable in proportion to the distance from the commencoment of incubation, and consequently to the space occupied by the embryo in the blastoderm. 